\title{
MINERAL RESOURCE POTENTIAL OF THE MOUNT RAYMOND ROADLESS AREA, CENTRAL SIERRA NEVADA, CALIFORNIA
}

\section{SUMMARY REPORT}

By

\author{
N. King Huber, Maurice A. Chaffee, and Andrew Griscom \\ U.S. Geological Survey \\ and
}

Donald O. Capstick and Stephen R. Iverson

U. S. Bureau of Mines

\section{STUDIES RELATED TO WILDERNESS}

Under the provisions of the Wilderness Act (Public Law 88-577, September 3, 1964) and the Joint Conference Report on Senate Bill 4, 88th Congress, the U.S. Geological Survey and the U.S. Bureau of Mines have been conducting surveys of wilderness and primitive areas. Areas officially designated as "wilderness," "wild," or "canoe" when the act was passed were incorporated into the National Wilderness Preservation System, and some of them are presently being studied. The act provided that areas under consideration for wilderness designation should be studied for suitability for incorporation into the Wilderness System. The mineral surveys constitute one aspect of the suitability studies. The act directs that the results of such surveys are to be made available to the public and be submitted to the President and the Congress. This report discusses the results of a mineral survey of the Mount Raymond Roadless Area, Sierra National Forest, Madera County, California. The area was classified as a further planning area (5-242) during the Second Roadless Area Review and Evaluation (RARE II) by the U.S. Forest Service, January 1979.

\section{SUMMARY OF MINERAL RESOURCE POTENTIAL}

The Mount Raymond Roadless Area has two types of metallic-mineral deposits or occurrences. One consists of silver-leadzinc minerals in aplitic dikes, and the other of concentrations of iron minerals in tactite zones near intrusive igneous rocks. Both types have been prospected since at least the early 1880 's.

The largest and only significant silver-lead-zinc surface mineral occurrence was developed in 1888-89 at the Star mine. After three failures to operate profitably, the mine has remained idle since about 1908. Production of silver and, possibly, lead was reported, but suspected to be very limited. The iron deposits, which are mostly peripheral to and just outside the roadless area boundary, have been explored, but not developed.

Field examination and data assessment indicate little potential for further production from the depleted Star mine ore bodies; low probability for further development of the Star mine property; and low resource potential for the remaining exposed Star-mine-type deposits situated nearby. On the basis of the sporadic and discontinuous characteristics typical of these deposits, we speculate that buried occurrences of this type would be randomly distributed within the host alaskite dikes, which also are poorly defined at the surface and undefined at depth. Such occurrences hold little promise as cost-effective exploration targets.

The iron-rich mineral deposits and occurrences have, similarly, a low potential for development. Deposits and occurrences are scattered, sporadic, and discontinuous, and the larger ones are outside the Mount Raymond Roadless Area. A minable resource would require the consolidation of enough separate deposits of high enough grade to justify development expenses. Such a proposal was made during the 1960 's, but development failed to materialize. Heavy-mineral concentrates from streams draining the areas of altered iron-rich metasedimentary rocks commonly contain anomalous amounts of an elemental suite (boron, bismuth, molybdenum, tin, tungsten) considered to characterize tungsten mineralization and indicate that at least some of the altered metasedimentary rocks contain possibly significant amounts of tungsten. Except for a narrow belt along the east side of the roadless area, the altered metasedimentary rocks lie outside the roadless-area boundary.

Heavy-mineral placer occurrences are not known or suspected to occur within the roadless area. Stone and sand and gravel suitable for construction materials are available in the area, but development and utilization for other than minor local demands are unlikely because similar or better grade materials are available nearer to major markets. There is no potential for fossil fuels in the roadless area.

\section{INTRODUCTION}

Area description

The Mount Raymond Roadless Area (study area) is in the Sierra National Forest, Madera County, California. It is on the west slope of the Sierra Nevada adjacent to the south boundary of Yosemite National Park (fig. 1), just east of the Mariposa Grove of Big Trees. The South Fork of the Merced River forms most of the north boundary of the roadless area, whereas the south boundary mostly follows a discontinuous ridge reaching elevations of $8712 \mathrm{ft}$ at Raymond Mountain and $9165 \mathrm{ft}$ at Iron Mountain. The Mount Raymond Roadless Area encompasses an area of 6,700 acres $\left(10.5 \mathrm{mi}^{2}\right)$. Access to the south and east margins of the study area is by several graded roads leaving State Highway 41 between the town of Oakhurst and the small community of Fish Camp.

\section{Previous investigations}

A geologic map of that part of the study area within the Merced Peak 15-minute quadrangle was published by Peck (1980), and that within the Shuteye Peak 15-minute quadrangle by Huber (1968). Neither of these maps, however, covers the site of the Star Mine, of particular interest in this study, and they do not consider mineral resource potential.

Mines and prospects in and near the study area were described in several California State reports covering the period 1888 through 1950 (California State Mining Bureau, 1888, 1906; McLaughlin and Bradley, 1916; Laizure, 1928; Logan, 1950) and in five U.S. Bureau of Mines property-examination reports during the 1940 's (Butner, 1947a, b; Benson, 1948; Witt, 1948a, b). 
Raymond Mountain was actually named "Mount Raymond" by the Whitney California Geological Survey in 1864, and the Annual Report of the State Mineralogist as early as 1888 referred to Mount Raymond and the Mount Raymond mining district. The U.S. Forest Service has continued this usage in naming the Mount Raymond Roadless Area. However, the earliest topographic-quadrangle map of the area (1897), and all subsequent topographic maps, name this peak "Raymond Mountain", and it is thus shown on the maps in this report.

\section{Present investigations}

The U.S. Geological Survey conducted geologic, geochemical, and geophysical investigations, and the U.S. Bureau of Mines conducted a site-specific mineral resource inventory, of the study area. A geologic map of the area has been published separately (Huber, 1982); the geologic and other studies are summarized in this report. The U.S. Forest Service facilitated this assessment by providing maps, records, and aerial photographs. Unpublished geologic mapping by Paul C. Bateman in the Bass Lake 15-minute quadrangle, by Dallas L. Peck in the Yosemite 15-minute quadrangle, and by John F. Slack in the vicinity of the Star mine, was made available for this study. David K. Denton, Jr., assisted ir the U.S. Bureau of Mines field studies, Julie A. Roller in the geologic studies, and Randall $\mathrm{H}$. Hill in the geochemical studies.

GEOLOGY, GEOCHEMISTRY, AND GEOPHYSICS PERTAINING TO MINERAL RESOURCE ASSESSMENT

\section{Geology}

The Mount Raymond Roadless Area is underlain by various plutonic rocks of the Sierra Nevada batholith and by metamorphic rocks that occur as septa or roof pendants within the batholith. Bedrock is well exposed on ridges and in glacial cirques, but much of the area is covered by talus and slopewash and, locally, by glacial moraine. Details of the geology and a fuller description of the geologic units are shown on a geologic map published separately (Huber, 1982).

Metamorphic rocks

Metasedimentary rocks occur at both the west and east margins of the study area and to the south of the study area. These rocks are predominantly quartz-rich varieties, ranging from fairly pure quartzite to quartz-mica schist and quartzite-pebble conglomerate. A narrow band of tactite, a metamorphosed carbonate rock, also projects into the northeast corner of the study area. The metavolcanic rocks are predominantly of pyroclastic origin; massive tuff and tuff breccia are most common. The metamorphic rocks are questionably of Jurassic and Cretaceous age.

Plutonic rocks

More than 80 percent of the study area is underlain by plutonic rocks of the Sierra Nevada batholith; rocks of three different plutons occur within the study area. The most extensive plutonic unit in the study area is the granite porphyry of Star Lakes. Alaskite and aplite dikes locally intrude the Star Lakes unit; in the vicinity of the Star mine, west of Raymond Mountain, they contain sporadic zones of silver-lead-zinc sulfide minerals. The other plutonic units in the study area are not known to host any mineralization. The plutonic rocks are inferred to be of Cretaceous age.

\section{Surficial Deposits}

The study area is near the west limit of glaciation at this latitude in the Sierra Nevada. During the last major glaciation, a trunk glacier in the canyon of the South Fork of the Merced River deposited lateral moraines 1,000 ft or more above the bottom of the canyon. About a dozen or so small glaciers, some of which fed into the trunk glacier, formed in northerly facing cirques and left their own series of lateral and recessional moraines. Talus and slopewash are abundant and mantle much of the study area, especially at the west end.

\section{Geochemical studies}

A total of 59 rock, 32 stream-sediment, and 32 heavymineral-concentrate samples were analyzed for the geochemical investigation of the Mount Raymond Roadless Area (Huber and Chaffee, 1973).

Rock samples containing anomalous concentrations of elements of potential interest are confined to two general areas: the area west of Cold Springs Meadow, and the area between Star Lakes and the west boundary of the roadless area. Each of these areas contains known mineral occurrences associated with outcrops of Jurassic or Cretaceous metamorphic rocks and Cretaceous plutonic rocks. The elements considered to be anomalous represent a suite that might be found associated with contact-metasomatic baseand precious-metal and (or) tungsten deposits. The overall anomaly levels in the rock samples not collected from obviously-mineralized outcrops range from low to moderate.

The most significant anomalies from the streamsediment and heavy-mineral-concentrate samples occur in the Rainier Creek, Long Meadow Creek, and White Chief Branch drainages along the southwest boundary of the roadless area, and in the Iron Creek and Cold Springs Meadow drainages in the eastern part of the study area.

In the southwestern part of the study area, the anomalies include an elemental suite (silver, arsenic, gold, copper, manganese, lead, zinc) considered to characterize base- and precious-metal mineralization. The most intense stream-sediment and heavy-mineral-concentrate anomalies are in the Rainier Creek drainage; however, these anomalies are probably, at least in part, the result of milling activity in that area related to development and production of the Star mine. Abandoned mine workings are also present in this drainage.

In the eastern part of the study area, the heavymineral-concentrate anomalies include an elemental suite (boron, bismuth, molybdenum, tin, tungsten) considered to characterize tungsten mineralization. Both Iron Creek and the Cold Springs Meadow area receive sediment derived from highly altered iron-rich metasedimentary rocks, such as those at the southern group of Myers prospects south of the roadless area and at the eastern group of Myers prospects adjacent to the roadless area. The anomalous metallic elements in the heavy-mineral concentrates of streamsediment samples are probably derived from these altered rocks.

\section{Geophysical studies}

An available aeromagnetic map of the Mount Raymond Roadless Area and vicinity was purchased from the U.S. Steel Corp. in 1981. Individual datum traverses along flightlines are east-west, with an average spacing of about $0.3 \mathrm{mi}$ over the areas of known mineralization. Height of the aircraft was a nominal $500 \mathrm{ft}$ above ground, the height being somewhat greater where it crossed valleys.

Examination of this aeromagnetic map, superimposed on the geologic map, indicates that some of the metamorphic rocks, particularly the metavolcanic rocks, are moderately magnetic, with anomalies ranging from 200 to 500 gammas in amplitude. Some of these anomalies appear to extend from the metavolcanic rocks into the undifferentiated metasedimentary rocks, but generally most of the magnetic features appear to be caused by rocks observed at the surface and to have no likely mineral resource significance.

Two anomalies of rather restricted extent are less easy to explain and may deserve further investigation, although all except a tiny part of one anomaly are outside the roadless area boundary. These anomalies consist of linear highs that flank the tactite unit and are about $0.3 \mathrm{mi}$ beyond the tactite contacts. Each represents a magnetic mass about $0.2 \mathrm{mi}$ wide and $0.9 \mathrm{mi}$ long. The western one may extend into the roadless area for about $500 \mathrm{ft}$ in the NE 1/4 sec. 12 , T. 5 S., R. 22 E. Hematite and magnetite occurrences are 
reported from this general area, and so the two anomalies may be caused by these magnetic iron oxides, somehow associated with the tactite. The amplitude of the anomalies is relatively small (300-500 gammas), and so that if they are caused predominantly by magnetite, they are probably not of resource importance.

\section{LOCAL, MINING ACTIVITY}

Silver-lead-zinc deposits located during the late 1800 's in the Raymond Mountain area (fig. 2, table 1) resulted in the organization of the poorly defined Mount Raymond mining district. The Star mine near Raymond Mountain was developed on the best of these sporadic and discontinuous silver-lead-zine deposits. The mine, served by an aerial tramway and mill, was opened in 1889 and is reported to have produced limited silver and, possibly, lead; it apparently failed to make a profit and was closed the same year. Thereafter, it was operated intermittently by at least two more owners until becoming permanently idle about 1908 . The small ore bodies were quickly depleted by open-pit methods, probably during the initial operations. Adequate recovery at the mill may also have been a problem.

Iron deposits west, south, and east of the Star mine and mostly outside the study area were explored at about the same time as the Star mine deposits. Although patents were granted on some iron claims, little was done to develop the claims. A proposal in the 1960's to consolidate these deposits into a single operation failed to reach development.

Gold placer deposits were discovered and developed to the south and southwest of the study area. Although placer exploration within the study area undoubtedly occurred, the results were apparently not encouraging.

The Strawberry tungsten mine, 12 miles east of the study area, has produced intermittently since World War II. Disseminated tungsten minerals are reported in the Star mine deposits but lack significance.

\section{ASSESSMENT OF MINERAL RESOURCE POTENTIAL}

The geology of the Mount Raymond Roadless Area consists of plutonic rock of the Sierra Nevada batholith that intrudes metamorphic rocks exposed in roof pendants. The reported and observed mineral occurrences are of two types. One type is associated with injections of late-stage alaskite dikes in contact-zone granitic rock. Deposits and occurrences found within this environment are of sulfides containing silver, lead, and zinc, and generally are confined to a small dike complex in a limited geographic area near Raymond Mountain. These mineral-bearing zones are typically sporadic and discontinuous within the dikes, and the largest zones are no more than $50 \mathrm{ft}$ in maximum dimension. The Star mine was developed on the best known surface exposures in 1888-89. Although production records are not available, the literature suggests that some silver and, possibly, lead was produced; the amounts are not thought to be significant. Mining has depleted the original deposits. Remaining occurrences at the mine are estimated to total about 4,300 tons of dike rock averaging 1.5 troy oz. silver per ton, 0.9 weight percent lead, and 1.9 weight percent zinc.

The second type of mineral occurrence consists of magnetite and other iron minerals in tactite bodies associated with carbonate-bearing metamorphic rocks. These sporadic and discontinuous deposits and occurrences are found over a wider area than those of silver-lead-zinc. In the 1960's, an attempt was made to consolidate numerous small iron occurrences along the south and east peripheries of the study area with larger ones farther to the south and east (U.S. Forest Service, 1965); however, the total resources apparently did not warrant the necessary investments. Therefore, these deposits are considered to have a low resource potential.

Heavy-mineral concentrates of sediment from streams draining the areas of altered iron-rich metasedimentary rocks commonly contain anomalous amounts of an elemental suite (boron, bismuth, molybdenum, tin, tungsten) considered to characterize tungsten mineralization and indicate that at least some of the altered metasedimentary rocks contain possibly significant amounts of tungsten. Except for a narrow belt along the east side of the roadless area, the altered metasedimentary rocks lie outside the boundary of the roadless area.

As a result of the activities associated with the mineral deposits just described, the Mount Raymond mining district was organized (California Mining Bureau, 1888). The primary focus of the district seems to have been the Star mine and its silver-lead-zinc occurrences. Development and production were limited to the Star mine workings. The iron resources associated with the district-few of which are known or suspected to be within the roadless area-probably have a low resource potential.

No heavy-mineral placer resources in the roadless area are known or suspected. Some potential may exist for stone and sand and gravel; however, development and utilization of these materials for other than minor local demands are unlikely because similar or better grade materials are available nearer to major markets.

The resource potential of the known mineral occurrences in the Mount Raymond Roadless Area is low. The probability of the presence of other silver-lead-zine and iron deposits or occurrences with resource potential is similarly low.

\section{REFERENCES CITED}

Benson, W. T., 1948, Preliminary report, Mount Raymond lead-zine property, Madera County, California: U.S. Bureau of Mines Property Examination, 6 p.

Butner, D. W., 1947a, Preliminary examination report, Star mine, Madera County, California, lead-zinc: U.S. Bureau of Mines War Minerals Examination, $4 \mathrm{p}$.

1947b, Summary Report, Star Mine, Madera County, California: U.S. Bureau of Mines War Minerals Examination, 2 p.

California Mining Bureau, 1888, Fresno County Section : State Mineralogist Annual Report 8, p. 202-216.

-1906, Iron Section, in Structural and industrial materials of California: Bulletin 38, p. 297-305.

Griscom, Andrew, and Huber, N. K., 1983, Aeromagnetic map of the Mount Raymond Roadless Area, central Sierra Nevada, California: U.S. Geological Survey Miscellaneous Field Studies Map MF-1417-D, scale 1:62,500.

Huber, N. K., 1968, Geologic map of the Shuteye Peak quadrangle, Sierra Nevada, California: U.S. Geological Survey Geologic Quadrangle Map GQ-728, scale $1: 62,500$.

-1982, Geologic map of the Mount Raymond Roadless Area, central Sierra Nevada, California: U.S. Geological Survey Miscellaneous Field Studies Map MF-1417-A, scale $1: 62,500$.

Huber, N. K., and Chaffee, M. A., 1983, Geochemical maps of the Mount Raymond Roadless Area, central Sierra Nevada, California: U.S. Geological Survey Miscellaneous Field Studies Map MF-1417-C, scale 1:62,500.

Laizure, C. M., 1928, San Francisco field division: California Division of Mines and Mining, State Mineralogist Report 24 , pt. 4 , p. $317-345$.

Logan, C. A., 1950, Mines and mineral resources of Madera County, California: California Journal of Mines and Geology, v. 46 , no. 4, p. 445-482.

MeLaughlin, R. P., and Bradley, W. W., 1916, Madera County, chap. 4 of Mines and mineral resources of $p$, tions of California: California State Mining Buresu, State Mineralogist Report 14, p. 531-568.

Peck, D. L., 1980, Geologic map of the Merced Peak quadrangle, central Sierra Nevada, California: U.S. Geological Survey Geologic Quadrangle Map GQ-1531, scale $1: 62,500$.

U.S. Forest Service, 1965, Multiple Use Survey report, proposed Mount Raymond-White Chief Mining Project: Sierra National Forest Review Draft, 6 p.

Witt, H. N., 1948a, Preliminary report on Mount Raymond mine (Smith-Bradford), Madera County, California: U.S. Bureau of Mines Property Examination, 5 p.

-1948b, Summary report on Mount Raymond: U.S. Bureau of Mines Property Examination, 2 p. 
Table 1.--Mines and prospects in and adjacent to the Mount Raymond Roadless Area

\begin{tabular}{llc}
\hline Name & Summary & $\begin{array}{c}\text { Number and } \\
\text { type of workings }\end{array}$ \\
\hline
\end{tabular}

Betty prospect
(iron and silver

(iron and silve)

Bluebell

prospect

(silver-lead-

zine)

Keystone

prospect

(silver-lead-

zine)

Lewis prospect

(silver-lead-

zine)

Myers prospect

(north)

(iron and silver)

Rio prospect

(silver-lead-

zinc)
Includes Wawona, Spar, Yellowstone, and, possibly, St. James, Rir, and Grand. Workings are in metav'clcanic and metasedimentary bedrock. The adits expose brecciated limonitestained quartzite containing gouge, magnetite, and minor malachite. Surface workings expose gray to green limonite-stained quartzite containing magnetite, sphalerite, and chalcopyrite.

May be included in Keystone prospects or SP group. Workings 600 $\mathrm{ft}$ west of Keystone prospect in a possible extension of the star mine aplite dike complex. White to light-gray, moderately to heavily limonite stained alaskite containing scattered chalcopyrite and surrounded by granodiorite.

May be included in SP group. Adit is driven northeastward into a pair of parallel shear zones with a maximum separation of about $5.5 \mathrm{ft}$ in bleached alaskite and granodiorite. Contained within this zone are sphalerite and galena in hard green fine-grained quartzite and tactite pods. Granodiorite is in near-vertical contact with an aplite dike to the east. The aplite is moderately to heavily iron-stained and contains scattered sphalerite.

Workings are in a white to gray north-trending alaskite dike, at least $17 \mathrm{ft}$ thick, exposed over a linear distance of about $500 \mathrm{ft}$ in granodiorite. The mineralized zones within the alaskite dike are heavily iron stained and contain some epidote and scattered concentrations of galena, sphalerite, and minor chalcopyrite. Exploration activities have in most places depleted known mineralized zones.

Located west of Cold Springs Meadow and may include Eagle prospects. Workings, spread over an area more than $1 \mathrm{mi}$ long (north-south) by $1 / 4$ mi wide, are located in a contactreplacement tactite zone. Most or all of the workings are outside the study area. Large concentrations of magnetite are indicated in the northernmost areas, and smaller amounts elsewhere. Metasedimentary rocks are epidote-pyroxene-garnet tactite or a green to black quartzite. Mineral-bearing rock in the northernmost areas contains primarily magnetite and sphalerite, but includes chalcopyrite and arsenopyrite.

May be grouped with the Betty prospects. Workings are in a northnortheast-trending discontinuous iron-stained white to medium-gray alaskite body in granodiorite. The alaskite is bleached in places or contains small tactite/scarn zones. Contains minor galena and chalcopyrite.
Three adits (one caved, one $52 \mathrm{ft}$ long, and one $12 \mathrm{ft}$ long), one shaft, one 88 -ftlong trench, and 10 small pits as much as $10 \mathrm{ft}$ wide.

One caved adit (20-40 ft of workings indicated by dump size) and one 15-ft-long pit.

Assays of 27 samples of quartzite gave 0.2 to 2.2 troy oz silver per ton, 0.05 to 5.5 weight percent zinc, and 0.09 to 0.5 weight percent lead; the one sample assayed for copper yielded 0.09 weight percent. Iron content of the magnetite samples ranged from 8.9 to 27 weight percent.

Assays of 2 samples of alaskite gave 0.2 and 1.0 troy oz silver per ton.

One 56-ft-long adit, one 15ft-long pit, and a bulldozer trench that may have destroyed an older adit or shaft; an old dump is adjacent to the trench.

Six pits as much as to $14 \mathrm{ft}$ wide and six trenches as much as 46 ft long.

Four adits as much as $94 \mathrm{ft}$ long, one 14-ft-deep shaft, at least six bulldozer trenches as much as $173 \mathrm{ft}$ long, seven hand-dug trenches (max $52 \mathrm{ft}$ long), and 12 pits ( $\max 26 \mathrm{ft}$ wide) on six patented claims and one millsite patent.

Two trenches as much as 32 ft long and six pits as much as $10 \mathrm{ft}$ wide. Most workings are within roadlessarea boundaries.
Assays of five samples of alaskite, one of granodiorite, and three of mixed granodiorite and alaskite gave 0.1 to 3.6 troy oz silver per ton, 0.08 to 1.2 weight percent lead, and 0.08 to 0.45 weight percent zine.

Assays of 10 samples of alaskite and two of 3.2 troy oz silver per ton, 0.01 to 0.17 weight percent copper, 0.01 to 11 weight percent lead, and 0.03 to 7.2 weight percent zinc. Two samples tested for arsenic contained 0.21 and 0.27 weight percent.

A ssays of 38 samples of tactite and quartzite contained iron up to "pure" magnetite (about 70 weight percent iron), 0.2 to 2 troy oz silver per ton, 0.01 to 0.8 weight percent copper, 0.03 to 22 weight percent zinc, and 0.01 to 0.15 weight percent lead. granodiorite gave 0.2 to
Assays of eight samples of alaskite and three of granodiorite gave 0.2 to 3.6 troy oz silver per ton, 0.01 to 0.8 weight percent lead, 0.15 to 2.5 weight percent zinc, and 0.02 to 0.16 weight percent copper. 
Table 1--continued

\begin{tabular}{|c|c|c|c|}
\hline Name & Summary & $\begin{array}{l}\text { Number and } \\
\text { type of workings }\end{array}$ & Sample data \\
\hline $\begin{array}{l}\text { Star Quartz } \\
\text { prospect (silver- } \\
\text { lead-zinc) }\end{array}$ & $\begin{array}{l}\text { All but two of the workings are in } \\
\text { frost-wedged granodiorite containing } \\
\text { no observable mineralized rock; the } \\
\text { other two, outside the roadless-area } \\
\text { boundary, contain white to light- } \\
\text { gray alaskite. An altered zone } \\
\text { within this alaskite is } 5 \text { ft long, } \\
\text { and as much as } 4 \text { in. thick; the zone } \\
\text { containing blebs of arsenopyrite as } \\
\text { much as } 1 \text { in. wide. }\end{array}$ & $\begin{array}{l}\text { Four trenches as much as } 42 \\
\text { ft long, three pits as much } \\
\text { as } 22 \mathrm{ft} \text { wide, and one } 9-\mathrm{ft}- \\
\text { deep shaft in a } 20-\mathrm{ft}-\mathrm{deep} \\
\text { pit. At least three of the } \\
\text { workings are outside the } \\
\text { roadless-area boundary. }\end{array}$ & $\begin{array}{l}\text { A total of } 10 \text { samples } \\
\text { taken, four of alaskite and } \\
\text { six of granodiorite. } \\
\text { Assays of the alaskite gave } \\
0.005 \text { to } 1.2 \text { troy oz gold } \\
\text { per ton, } 0.2 \text { to } 4.6 \text { troy oz } \\
\text { silver per ton, and } 0.04 \text { to } \\
0.26 \text { weight percent lead; } \\
\text { one sample contained } 8.0 \\
\text { weight percent arsenopyrite }\end{array}$ \\
\hline $\begin{array}{l}\text { Starlight } \\
\text { prospect (silver- } \\
\text { lead-zinc) }\end{array}$ & $\begin{array}{l}\text { Trenches are in granodiorite with } \\
\text { "stockpiles" of iron-stained } \\
\text { granodiorite at one end. The pit } \\
\text { contains a minor exposure of white } \\
\text { iron-stained alaskite with vugs and } \\
\text { epidote crystals. Garnet-epidote } \\
\text { zones and galena- and iron-stained } \\
\text { boxworks are within the alaskite. }\end{array}$ & $\begin{array}{l}\text { Two trenches as much as } 50 \\
\text { ft long and one } 13-\mathrm{ft}-\text { wide } \\
\text { pit. }\end{array}$ & $\begin{array}{l}\text { Three samples taken. } \\
\text { Alaskite from pit contained } \\
3.2 \text { troy oz silver per ton } \\
\text { and } 0.15 \text { weight percent } \\
\text { zinc. }\end{array}$ \\
\hline
\end{tabular}




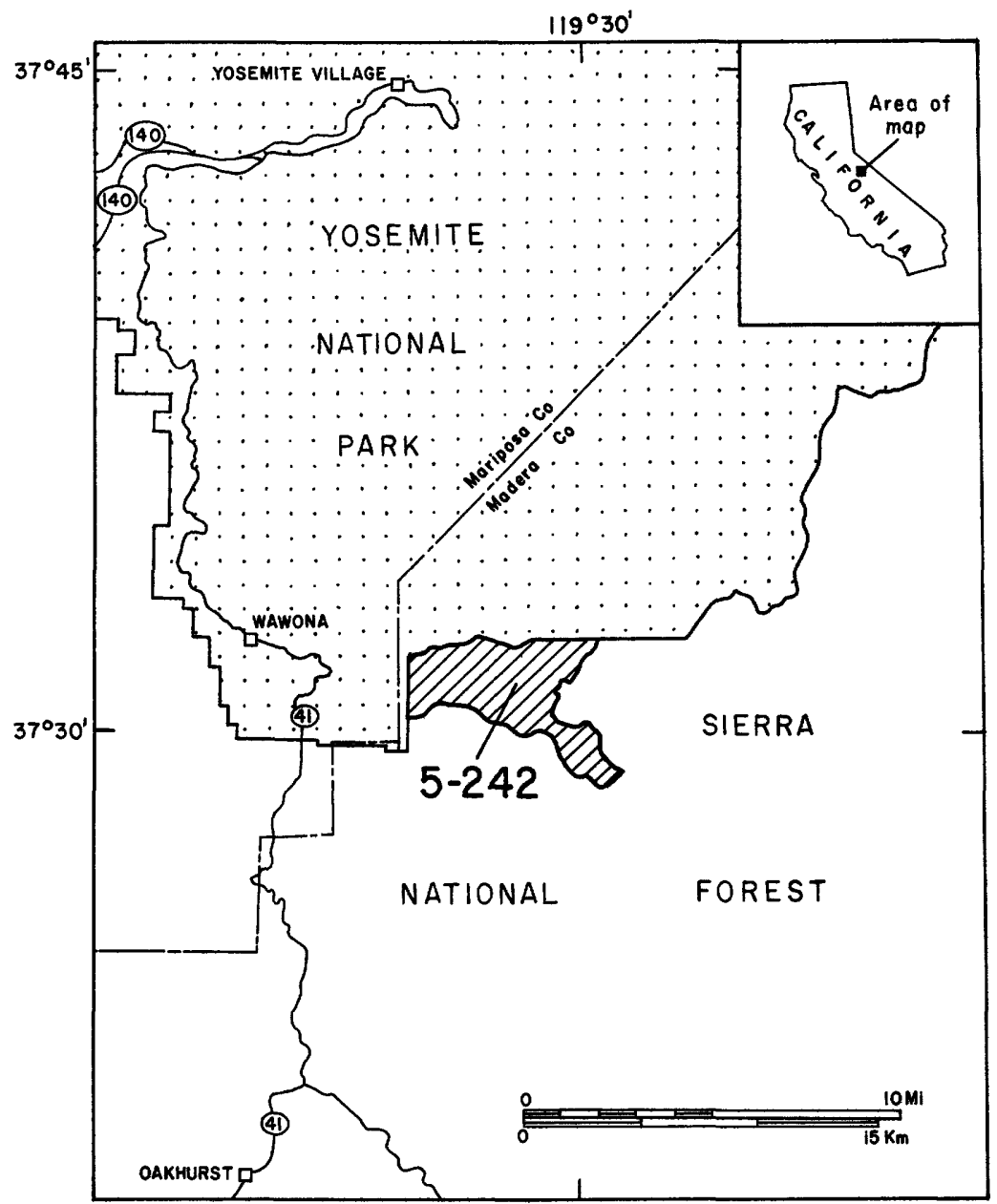

Figure 1.--Index map showing location of Mount Raymond Roadless Area (diagonal lines) in east-central Cali fornia. 


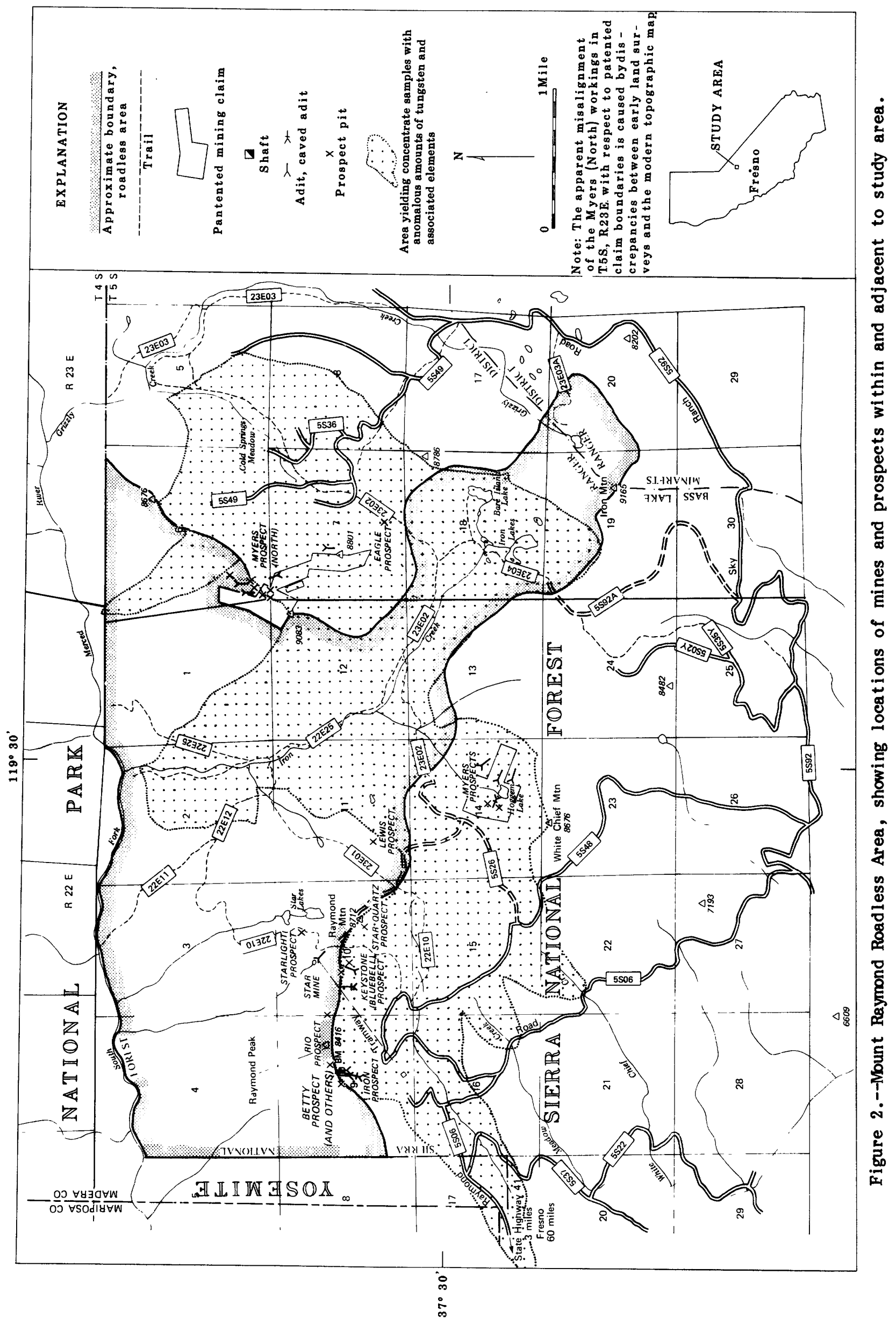


